\begin{tabular}{c}
\hline Review of \\
ECONOMICS \\
and \\
INSTITUTIONS
\end{tabular}

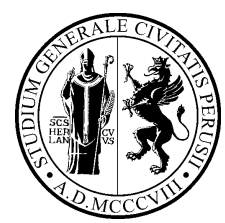

www.rei.unipg.it

\title{
Multinational Firms and the Pursuit of Social Benefits
}

\author{
Antonello Zanfei \\ University of Urbino
}

\begin{abstract}
It is argued that a new actor is emerging in international business, which can be dubbed "Social Multinational", that is a blend of international rent-creation and pursuit of social objectives. However, it would be misleading to state that the emergence of Social Multinationals will be the natural outcome of a market driven process. Too much is left to the understanding and sensitiveness of individual entrepreneurs. Signals of the emergence of this new and promising breed are still very weak. Important institutional innovations will have to be enacted to favour its strengthening and growth.
\end{abstract}

JEL classification: F23, L26, M14

Keywords: multinational firms, social responsibility, spillovers

$\triangle$ Address: Department of Economics, Society and Politics (DESP), Faculty of Economics, University of Urbino - Via Saffi 42, 61029 Urbino, Italy. (Phone +39 0722 305562, Fax +39 0722 305550, Email: antonello.zanfei@uniurb.it).

\section{Recommended Citation}

Zanfei, A. (2011). Multinational Firms and the Pursuit of Social Benefits. Review of Economics and Institutions, 2(3), Article 3. doi: 10.5202/rei.v2i3.35. Retrieved from http://www.rei.unipg.it/rei/article/view/35 


\section{Introduction}

Multinational firms (MNFs) are normally considered as a good means to pursue private benefits often at a cost for society as a whole. And this is by and large a correct perception, at least as a general statement. The relationship between MNFs and social interests could be described as the case of a rich and cumbersome person in a crystal item shop: he or she may be a good spender, induce other wealthy customers to come in, but he/she is most likely to hit something delicate and produce a serious damage. The bottom line is the idea that MNFs do generate some positive externalities, but once negative externalities are also taken into account, the overall effect may well be null or negative. This view is consistent with the outcome of a plethora of case studies, but also with a large number of multivariate empirical analyses on the effects of foreign presence on the productivity of host economies, however this may be measured, especially when using panel data techniques (Görg and Greenaway, 2004; Castellani and Zanfei, 2006; Haskel et al., 2007).

However, under specific economic, technological and institutional circumstances, one may envisage the emergence and growth of a new actor in international business which we shall refer to as "Social Multinational". This can be seen as a specific application of the concept of "social business" that has been recently introduced in the literature, which identifies a value generating activity whose purpose is to address and solve social problems (Yunus, 2008a; Yunus, 2008b).

As we shall illustrate, the concept of Social Business should be kept separate from that of Corporate Social Responsibility. The latter can be considered as a way of taking care of the well being of all stakeholders (and not only of shareholders) in order to generate goodwill, improve business environment, and increase the social acceptability of value creating activities (Asongu, 2007). The key feature that brings us to distinguish these activities from Social Business consists in the locus in which economic value is generated. In the case of Social Responsibility strategies, value is not created directly through social activities, which are normally not self-sustaining. A surplus will be generated through better performances elsewhere, that is in other corporate lines of business, different from social activities. This will occur if the extra-costs met in pursuing social objectives (e.g., better health, housing or education for workers) is more than compensated by savings stemming from the reduction of social conflict, or by extra profits that will eventually derive from more motivated stakeholders, including workers and well informed consumers. By contrast, in the case of Social Business, socially oriented activities are themselves supposed to be sources of economic value. These activities should be undertaken in a way that is at least self-sustaining and, if some economic surplus is generated, it should be used to improve the level of attainment of social objectives. 
Much like other forms of Social Business, Social Multinationals can be seen as the expression of a different form of entrepreneurship, corresponding to an often disregarded dimension of "homo economicus". That is, it corresponds to the innate tension of human beings to improve the (overall) environment in which they live and operate. What makes the difference with other Social Businesses carried out at a national level, is that this innate tension is here combined with the advantages of multinationality. From this perspective, Social Multinationals are more powerful as a vehicle of social benefits. As multinationality is associated with both ex ante, proprietary advantages and ex post, learning advantages, one can expect that they will generate greater surpluses that will translate into higher social benefits.

A few examples are there to show that this blend of international rentcreation and pursuit of social objectives is possible. However, it would be misleading to state that the emergence of Social Multinationals will be the natural outcome of a market driven process. Too much is left to the understanding and sensitiveness of individual entrepreneurs. Signals of the emergence of this new and promising breed are still very weak. Important institutional innovations will have to be enacted to favour its strengthening and growth.

The paper is structured as follows. Section 2 illustrates some scattered empirical evidence on the emergence of Social Multinationals. Section 3 recalls different lines of analysis of the links between multinational activities and socio-economic progress. Section 4 outlines the building blocks of the notion of Social Multinational. Section 5 focuses on factors favouring the emergence and strengthening of this new actor in international business.

\section{Illustrative Evidence of the Emergence of So- cial Multinationals}

The first application of the idea of Social Business dates back to the second half of the 1970's with the development of Grameen Bank in Bangladesh, followed by a proliferation of micro-financial institutions aimed to make credit accessible to the poor. These institutions represent a fundamental innovation in financial markets as they target people with very low standard of living and no proprietary assets as a guarantee, which will make it impossible for them to obtain a loan from standard banks. What makes of Grameen Bank an example of Social Business is first of all the fact that it allows to remove a very binding financial constraint to self-employment and more generally to the development of income generating activities for the have-not people, thus contributing to poverty reduction. Furthermore, the economic surpluses generated through these activities remain to the poor, who benefit from the Bank's growth and revenues. As specified by Yunus (2008a, p.7): "The borrowers buy Grameen Bank shares with their own money, and these shares cannot be transferred to non borrowers". Today 
Grameen Bank lends money to 7.5 million borrowers, 97 per cent women. The bank has lent out over $\$ 7.0$ billion in Bangladesh over the years, with over $90 \%$ alleged reimbursement rates (Yunus 2008c, p.2). While these businesses were originally conceived to tackle specific objectives related to poverty reduction in Bangladesh, part of them were bound to become international and to spread on a global basis.

Microfinance institutions belonging to Grameen Group were the first Social Businesses to go global. Starting in 1989 Grameen Trust has been operating to provide training and technical services to firms carrying out microfinance services around the world. It has now reached up to 40 different countries where Grameen has either opened activities in joint venture with national firms or has assisted independent institutions locally.

While micro-credit has become a profitable activity also for many other institutions, not necessarily owned by cooperatives of poor people, this service is still primarily offered to the poor and represents an example of how Social Business can become international.

It is not easy to quantify the importance of this phenomenon. As noted by UNCDF (2005, p.9): "In microfinance, the availability of hard financial sector data to answer the simple question of "who has access to what, and what is the quality of that access?' is nearly impossible to come by." The size of the market is hard to estimate both on the supply side, as a number of micro-organisations, ONGs and non-profit organisations are involved in this business as part of their activities; and on the demand side, as both the poorest and the less poor could be interested in gaining access to the service and cannot be easily distinguished one from the other. International databases thus generally report data only on what could be considered as the top of the iceberg, and do not always distinguish between national and international micro finance institutions. The MicroCredit Summit (MCS) database publishes a yearly summary report of outreach statistics on the microcredit industry. The 2007 report included information on 3,316 microcredit programs offered to some 133 million clients, about 90 million of whom fall into the "poorest clients" category (Daley-Harris, 2007). BlueOrchard.org, a Swiss private consulting company, estimates the existence of some 10.000 micro-finance institutions, hence allowing us to assume that minor organisations below the "iceberg top", not covered by official datasets, are about 7.000. According to the 2007 MicroBanking Bulletin (MBB) 9\% of world micro-finance institutions capture some $75 \%$ of total clients (Nelson, 2007). Overall the actual size of the market is estimated between USD 20 billion (BlueOrchard) and 30 billion (Social Enterprise Associates), which would make between $5 \%$ and $10 \%$ of the potential demand for micro-finance products.

Micro-finance business is certainly the most established and internationally widespread of socially oriented activities started by the Grameen Group in Bangladesh. However, in recent years, several international operations 
were carried out, most often in the form of joint ventures, to exploit new market and technological opportunities. Once again these businesses were designed as profitable activities, but with the aim, explicitly stated in the contracts signed with partner companies, to ensure the sustainability of the joint venture, so that the products or services they provided could reach more and more of the poor. Among these international operations one should mention the creation of Grameen Phone in 1996 as a joint venture between Grameen Telecom, a non profit company, and Norway's Telenor, Japan's Marubeni, and Gonofone Development Co. of USA, to commercialise mobile services in Bangladesh. As explicitly stated in a memorandum of understanding signed when the company was founded, this joint venture should have been the preliminary move to develop local technical and marketing capabilities to be exploited in the national and international markets, and should have led to a complete control of operations by Grameen Telecom, whose assets are owned by the poor people of Bangladesh. This transformation of a for profit joint venture into a Social Business activity owned directly by the poor, is facing some problems as Telenor is not accepting to honour the agreement originally signed.

More recently, in September 2007, Grameen Solution, the Group's company founded in 1999, specialised in office ICT equipment, has entered a collaborative venture with Intel of US, aimed to design wireless (Wimax) and ICT services for educational purposes.

Another promising activity branching out into international markets is Grameen Health Care Services, founded in 2006, which has opened several hospitals specialised in Ophthalmology services. Using personnel trained in India, this company is organised as a very innovative multinational offering highly qualified services with "Robin Hood tariffs": Standard customers pay full prices, while the poor pay lower tariffs. The idea is to open new hospitals in other Asian and African countries with the financial support of Grameen Health Trust, and extend the same practice ${ }^{1}$

The concept of international Social Business got at center stage when Grameen Bank launched a joint venture with Danone, a multinational company from France. Grameen teamed up with Danone to bring nutritious fortified yogurt to the undernourished children of rural Bangladesh. The aim of this Social Business is to fill the nutritional gap in the diet of these

\footnotetext{
${ }^{1}$ Financial links between different companies of the Grameen group have raised some concern in international public opinion, due to the alleged possibility that funds be unduly diverted from activities targeted to poverty reduction. A documentary of Norwegian TV circulated in December 2010 and subsequent media reports (launched by BDNews24 news agency) pointed out that Yunus would have diverted \$100 million meant for microcredit lending of Grameen Bank to its sister venture Grameen Kalyan, also a non-profit welfare company breeching Bangladesh's financial laws and agreements with the donor, the Norwegian aid agency Norad. The donor itself has given a clean chit to Grameen Bank founder, saying it found no evidence of fund embezzlement by his bank, removing a cloud that had hovered over the Nobel Laureate (http:/ / www.rediff.com).
} 
children. The joint venture sells yogurt to the families of poor children at an affordable price, charging just enough to make the company self sustaining. Beyond the return of the original investment capital, neither Grameen nor Danone will make any money from this venture, by agreement. Net returns of investments are supposed to be reinvested to ameliorate and extend the existing activities, with the poor extending their control on the venture by acquiring increasing shares of the capital through their participation in Grameen Bank's assets. Besides, workers at Grameen Danone are encouraged to buy shares of the company as part of their salaries. In 2007 one yogurt plant was already operating in Bangladesh, and the expectation is to have 50 such plants throughout the country in the next few years.

Grameen Danone is the first case of (almost) pure Social Multinational launched in recent years. Other more recent examples include a joint-venture with Veolia of France to deliver safe drinking water in the villages of Bangladesh. This joint venture is building a small water treatment plant to bring clean water to 50,000 villagers, in an area of Bangladesh where the existing water supply is highly arsenic contaminated. Purified water will be sold at an affordable price to the villagers to make the company sustainable, but once again no financial gain will come to Grameen or Veolia (Yunus, 2008c, p.3).

\section{Multinationals and Social Benefits. Trade Offs and Complementarities}

How can multinationals be beneficial to society? The answer to this question can be given along three distinct lines. The first one considers under which circumstances the international operations carried out by profit maximising multinationals can generate (net) positive spillovers to the different (home and host) countries in which they are active. From this perspective, multinationals can be beneficial to society to the extent that positive externalities, potentially stemming from their superior technology and managerial abilities, exceed negative spillovers that are associated to their market power and monopolistic control of the economies in which they operate. See Blomstrom and Kokko (1998), Zanfei (2005), Castellani and Zanfei (2006), Driffield and Love (2007) for reviews of theoretical and empirical research along this line of analysis.

A second way to assess the social benefits associated with multinational behaviour consists in examining whether and how multinationals can get involved into additional lines of activities that are not profit oriented. This corresponds to the increasing emphasis given by scholars and practitioners to Social Responsibility, and to Social Entrepreneurship, as complementary to profit oriented activities of firms, especially when exposed to international competition. The idea here is that MNFs can be particularly interested in investing in welfare sensitive areas as part of a more general strategy to 
ameliorate their business environment (hence leading to improved productivity) and to increase their social acceptability. These activities, which are not conceived as economically self-sustaining, will be carried out up to the point at which the extra-costs associated to them is more than compensated by the advantages accruing to the MNF from their core businesses. That is, cost savings stemming from the pre-emption of social conflicts and/or regulatory measures and extra-profits eventually generated by higher productivity of more motivated workers. See Hollander (1990), Egri and Ralston (2008), Asongu (2007) for extensive reviews of theoretical and empirical work along this strand of research.

The third line still largely needs to be explored in the literature. The idea is to examine under which circumstances multinationals get involved into international operations expressly aimed to social objectives (e.g., improvement of health, of nutrition, of education, or more generally, poverty reduction) generating economic surpluses that are further utilised to pursue the same social objectives. Multinationals adopting this line of conduct, which we have named Social MNFs, can be expected to have a high, positive and self-reinforcing positive effect for society.

So far there has been rather sound empirical research on the effects of micro-finance business carried out by a variety of national and multinational firms on income and consumption in LDCs. 3 By contrast there is only anecdotic evidence on the development of Social Multinationals in other areas of business.

Suffice here to observe that there are signals that whenever multinational activities are organised according to lines that are at least broadly consistent with this emerging model, social effects tend to be positive and significant. This motivates a further analysis of the nature of social MNF and of the conditions underlying its emergence, survival and growth.

\footnotetext{
${ }^{2}$ The most influential studies were conducted by Pitt and Khandker (1998) who, using data from a survey of some 1,800 households in rural Bangladeshi villages in 199192, where Grameen Bank already had a relatively long tradition, concluded that microcredit increases household spending, especially when given to women: "[A]nnual household consumption expenditure increases 18 taka for every 100 additional taka borrowed by women... compared with 11 taka for men." The dataset was updated and augmented in 1999, allowing Khandker (2005) to better control for endogeneity and sample selection biases, and to further reinforce the original conclusion. Collins et al. (2009) carry out in-depth study of "financial diaries" of dozens of households in Bangladesh, India and South Africa over relatively long periods of time. Based on this research, they make no claim that microfinance raises income on average, but they do argue that microfinance is valuable in helping people smooth that income. Other studies by Roodman and Morduch (2009), using the same data from Bangladesh as Khandker's but applying quasi-experimental techniques, reach less clear-cut conclusions. Niño-Zarazúa (2009) working on data from urban Mexico, finds no evidence of impacts on extreme poverty but observes a link between poverty impacts and technology lending.
} 


\section{The Nature of Social Multinationals}

As shown in section 2, there is some evidence of the existence of this relatively new and still rare breed that we have identified as "Social Multinational". In section 3 we have argued that this institution can be expected to generate high social benefits, possibly higher than other types of multinationals. Let us now turn back to the very concept of Social Multinational, to better define its nature and characteristics.

\subsection{Typologies of (International) Social Business}

There are two basic typologies of Social Business, as identified by Yunus (2008b), who first introduced the concept, which we shall adapt to better define our idea of Social MNF. Both typologies share an explicit orientation to pursue social objectives (e.g., extending the access to merit goods, such as health and education, improving the quality of life in depressed areas, reducing poverty and its consequences). As we anticipated earlier, the pursuit of these objectives will have to be consistent with the generation of some economic surplus that will be used to further increase social well being. It is important for the definition to hold, and in order to distinguish this category from others (e.g., Corporate Social Responsibility), that the activity leading to the attainment of such social objectives be at least self-sustaining (no loss), and that the surplus, if any, is devoted to social objectives. Based on this common ground, a first typology of social firm is one that is owned and/or financed by investors, who may not be poor nor deriving any direct benefit from the social action of the firm. For instance a pool of entrepreneurs of the first world investing their capitals to build a water pipeline to serve a village in a Less Developed Country. Different from pure profit business, surpluses would not be distributed to share-holders, managers or other stakeholders, but be reinvested to improve the quality of the product or service that is designed to attain the social objective (in this case the extension and quality of water services to the poor). This would be the "no loss - no dividend" type of Social Business.

The second typology is a business owned by the poor. In this case even profit maximising activities can be considered as Social Business. In fact its social mission will be to provide revenues and profits that go to the benefit of people with very low or no income, hence contributing to a socially sensitive objective, that is the reduction of poverty. An example of social enterprises of this nature is Grameen Bank. But it is also the case of similar micro-financial institutions taking the form of cooperatives owned by the low income borrowers to which their services are directed. This would be a "no loss-dividends to the poor" type of Social Business.

The case of Grameen Danone which we have recalled in section 2 is a combination of these two typologies of Social Business. As co-owner of the 
joint venture, Danone contributes its technical and managerial competencies to ensure the cost effectiveness of the activity and the generation of a positive surplus from it. Moreover, the French group also accepts by contract to give up all pretensions to distribute dividends to its stake-holders. Benefits accruing to the poor are threefold. First, a low price, high quality yogurt is made available to poor families as a key complement to their nutritional practices. Second, revenues are granted to the low income families owning stocks of Grameen Group, which participates to the joint venture with Danone. Third, the poor will benefit from reinvestments of profits obtained by Grameen-Danone as a result of a well managed business plan.

\subsection{The Economic Rationale of (International) Social Busi- ness}

Is there any economic rationality underlying the choice of doing (international) Social Business? It might appear that this choice either relies on non-economic factors (e.g., political pressures on governments to increase aid on firms to increase their social commitment); or represents a paradox from an economic point of view. However, this perception is heavily influenced by dominant methodological individualism characterising today's economic approaches. The generally accepted idea is that the marketplace is only for those who are interested in the selfish appropriation of profit. As argued by Yunus (2008a, pp.5-6), this interpretation treats people as onedimensional beings. But people are multi dimensional: while they have their selfish dimension, at the same time, they also have their selfless dimension. And the presence of the latter helps explain why certain activities generating economic value are undertaken. Yunus himself notes that this is an old idea that traces back to two and a half centuries ago, to Adam Smith's Theory of Moral Sentiments. Using Adam Smith's words:

"How selfish so ever man may be supposed, there are evidently some principles in his nature, which interest him in the fortunes of others, and render their happiness necessary to him, though he derives nothing from it, except the pleasure of seeing it. Of this kind is pity or compassion, the emotion we feel for the misery of others, when we either see it, or are made to conceive it in a very lively manner. That we often derive sorrow from the sorrows of others, is a matter of fact too obvious to require any instances to prove it; for this sentiment, like all the other original passions of human nature, is by no means confined to the virtuous or the humane, though they perhaps may feel it with the most exquisite sensibility. The greatest ruffian, the most hardened violator of the laws of society, is not altogether without it."

Smith took the view that people are born with a moral sense combined with a natural fellow-feeling, which he calls "sympathy". These feelings are 
innate, like the inborn ideas of beauty or harmony. From this perspective, the sense of what is right and wrong is also innate, not something given us by lawmakers or by rational analysis.

With these ideas in mind, Yunus (2008a, p.7) suggests that Smith's key thesis put forward in The Wealth of Nations, that "self interest" is the engine of economic activity, has probably been misunderstood: "The world has interpreted 'self-interest' as equal to profit maximization. But with human beings as they are, driven by conscience and sympathy as well as the desire for profit, we see that 'self-interest' includes both profit maximization and social contribution." (Yunus, 2008a, p.7).

Hence, the pursuit of social objectives is not only consistent with selfinterest: it is part of it. It fuels economic behaviour as does the private appropriation of profits. And this provides a strong rationale for Social Business.

The dominant view has been that the selfless dimension of human being will motivate either the behaviour of non profit institutions as well as the charitable efforts of individuals; or Social responsibility strategies aimed to reinforce long term advantages of for profit firms. However, this is only part of the potential expression of this human dimension, and not even the most productive in terms of social benefits. As highlighted by the past experience of micro-finance business, there is an extensive, largely un-organised and very promising, international market potential for Social Business. This market needs to be structured to attract talented entrepreneurs, who would otherwise express their selflessness through charities or social responsibility actions, and induce them to invest into rent creating activities aimed to social objectives. ? $^{3}$

\subsection{When Social Business Goes Global}

A special case of Social Business is Social Multinationals. This is not only a matter of size and geographic diversification. Like other multinational enterprises, by extending their reach across different countries, Social MNFs are characterised by at least two peculiar features. First, they can rely upon some sort of ex ante advantages (technological, organisational, managerial,

\footnotetext{
${ }^{3}$ As Yunus (2008a p.7) has noted: "Some people are skeptical when I describe the concept of social business. Who will create these businesses? Who will run these businesses? Why would anyone devote time, energy, and money to projects with no hope of personal gain? I always say that, to begin with, there is no dearth of philanthropists in the world, no dearth of donor countries giving grants. People give away billions of dollars every year. So do donor countries. Imagine if those billions could be used by social businesses to help people. These billions would be recycled again and again, and the social impact could be all that much more powerful. In the same way, money allocated by companies to corporate social responsibility projects could easily go into social businesses. Each company would create its own range of social businesses. We can also create Social Business Funds to pool funds from many sources and invest them in social businesses. The opportunities for launching social businesses are really limitless".
} 
financial). These advantages reflect a process of self-selection which allows only the best performing firms and institutions to cost-effectively gain access to foreign markets. Second, thanks to the geographical spread of their activities, they will be able to gain access to a larger set of market and technological opportunities than uni-national firms. ${ }^{4}$ What is peculiar of Social MNFs and distinguishes them from other multinationals is that profits are not appropriated but re-used to better achieve social objectives. As mentioned earlier, this will occur either in the form of dividend distribution, if the activity is owned by the poor; or in the form of reinvestment to ameliorate performances, in the case of "no loss-no dividends" MNFs. What makes the difference with other Social Business carried out at a national level, is that the combination of ex ante and ex post advantages that characterised all multinationals is likely to generate higher social benefits than in the case of Social Businesses carried out within the boundaries of an individual country. Moreover, multinationality allows firms to spread the costs of Social Business over larger markets, and to apply knowledge accumulated by doing Social Business to a variety of other contexts as well.

The considerations above imply that multinationals are in a better position than uni-national firms to operate where there is some social problem to tackle. They will generally have more financial and managerial resources to use where needed (multinationality advantages used to improve performances of Social Business). They will also be able to re-use elsewhere intuitions and lessons learned from the activities carried out where the social activity is being carried out (learning from Social Business).

Both effects can be observed in the already mentioned case of GrameenDanone. Danone brought in its ability to mobilise financial resources from rich markets. In 2007 a new mutual fund was created, named Societé d'Investissement à Capitale Variable (Sicav) "Danone Communities", whose assets are $90 \%$ invested to yield normal interest rates, and $10 \%$ devoted to social activities, including yogurt production in Bangladesh. Promoted by Crédit Agricole of France, this fund targets Danone's stock-holders, institutional investors, and individual customers. Investors know that $10 \%$ of the fund would yield no interests. Hence the overall revenue from this investment would be slightly less than average interest rates, but would be able to contribute to programs aimed to satisfy needs of the poor.

The French group also contributed its technical abilities for the production and commercialisation of yogurt, developed in its long experience in a large number of markets. These skills were applied to the design and implementation of plants, to product development and to packaging. It could also mobilise a powerful worldwide promotion campaign. The new yogurt production line was launched making use of a universally known French soccer player (Zidane) as a testimonial, a marketing move that only a multinational

\footnotetext{
${ }^{4}$ See Narula and Zanfei (2005) for a review of the literature concerning both types of (ex ante and ex post) advantages related to multinational expansion.
} 
could afford. This contributed to ameliorate Danone's international reputation, but also drew world attention to the specific Social Business project and attracted potential investors to the new mutual fund created to finance it.

There are also several examples of learning from Social Business generated by the Grameen-Danone experience. As production facilities had to integrate as much as possible into the territory, reduce all environmental impacts and encounter the maximum social acceptance, Danone's engineers were put to work with the aim of re-designing plants and process technologies. They eventually got to reach a more than acceptable level of technical efficiency at the lowest end of production scale, an outcome that could easily be replicated in other countries where similar territorial constraints apply.

Products were also adapted to better encounter local taste requirements, through the development of a new sweetening procedure based on the use of palm dates molasses. Commercialisation chains were revised to reflect once again the objective of integrating production into the territory. The state of roads and of local distribution channels was not consistent with the standard delivery procedure, based on the use of large, refrigerator equipped trucks transporting the product to refrigerator equipped points of sale. The solution that eventually emerged was to involve dozens of individual selling agents, that is local women highly motivated and convinced of the product quality, each delivering small lots of fresh yogurt directly at street markets and often placing the product door by door in nearby villages.

One form that could be given to Social Multinational activities is the creation of a local company initially financed by foreign entities, up to the point when revenues generated by the activity allow to reimburse foreign investors, gradually leaving the property of production means to local stakeholders. Local workers (including managers) will receive shares of the company as part of their salaries, which they will be free to sell (to other poor and committed people) or keep to participate to the ownership and control of the company. As Yunus (2008a) suggests: "Bilateral and multi-lateral donors interested in supporting economic development could easily create Social Businesses of this type. When a donor wants to give a loan or a grant to build a bridge in the recipient country, it could create instead a 'bridge company' owned by the local poor. A committed management could be given the responsibility of running the company. Part of the profits earned by the company would go to the local poor as dividends, while part would go towards building more bridges. Many infrastructure projects, like roads, highways, airports, seaports, and utility companies could be built in this manner". 


\section{Factors Favouring the Emergence of Social Multi- nationals}

It may appear that what we have called the "selfless component of selfinterest", i.e. the pleasure deriving from the welfare of others, is less powerful an engine of economic activity than is the investor's selfish expectation that surpluses will be appropriated. However, by comparing how effective and growth enhancing are for profit activities and Social Business we are actually assimilating apples with pears. Firms adopting a profit maximisation perspective are active in well organised markets, protected by institutions (norms and codes of conduct) with a long history which have been shaping (selfish) economic behaviour over centuries. By contrast, Social Business is a relatively recent breed, and there exists virtually no institution to govern its development.

In spite of this lack of institutions governing the market for Social Business, important facilitating factors have come to work during the two final decades of the XX century. Some of these forces are the same that favour the development of other expressions of the selfless dimension of human beings, such as charitable efforts and Corporate Responsibility strategies. These include neo-liberist pressures on States to withdraw from the provision of social services, that have induced a growing demand for other providers of social services, including the third sector, charity institutions and socially committed enterprises (McDonald and Martson, 2001; Dart, 2004).

Other more specific forces are pushing multinationals to pay more attention to social objectives. On the one hand, a growing concern in the public opinion on the alleged negative effects of globalisation is urging MNFs to increasingly care about perceived social impact of their action. Starting in the second half of the 1990's a number of positions have emerged militating against globalisation. Kaldor et al. (2003) identify these as "rejectionists" i.e. those in favour of greater protection of national economies and of stricter regulation on MNFs. Although these positions have had limited consideration in the academic debate, they have been very influential thanks to a number of columnists in leading newspapers and magazines, and to the authors of pamphlets addressed to a wide non technical audience, as it is the case of Naomi Klein and Ralph Nader among others. These opinion leaders have not been able to invert the relatively benign attitude of host governments vis a vis multinational activities, nor have they put a real brake on the "race for foreign investments" engaged by many developing countries. Nevertheless, the trend towards more favourable regulation for foreign investors that could be observed in the 1990's seems to have arrested at the turn of the new century. The share of less favourable regulatory changes introduced by national governments vis a vis foreign investors has mono- 
tonically increased from $2 \%$ of all the 150 legal measures modified by 70 countries in year 2000, to $20 \%$ of the 177 measures introduced by 91 countries in 2006 占(Unctad, 2008).

On the positive side, one could mention a variety of converging forces. First, the worldwide diffusion of information and communication technologies can be expected to have, inter alia, an impact on Social Business, by generating new organisational opportunities for both large multinationals and small local enterprises. On the one hand, by reducing the costs of coordinating international activities, it will facilitate adding new lines of socially oriented businesses to the ones normally carried out by for profit multinationals. On the other hand, ICTs are powerful tools to enhance the success of small businesses and entrepreneurs to be successful, grow and generate a positive social impact in their immediate environment (Socinfo, 2009).

Second, the philanthropic behaviour of top managers of large companies, especially multinationals, have always been a reality and have normally received a wide and growing coverage by all media, and has drawn an increasing attention also by academics. The more recent involvement of some multinational companies into Social Business (see section 2) has further attracted the attention of public opinion. These patterns of entrepreneurial behaviour are increasingly perceived as a powerful marketing strategy, and tend to have remarkable demonstration effects. One might venture saying that creating new lines of Social Business might become an accepted (endogenous) cost in markets exposed to international competition (Asongu, 2007).

Third, the diffusion of Social Multinationals might also be favoured by the past expansion and economic success of microfinance as a business area with important social consequences especially in LDCs (Khandker 2005, Collins et al., 2009). Among other consequences, the international recognition of the actual and potential impact of these activities on income creation and poverty reduction, has eventually led to a Peace Nobel Prize awarded to Muhammad Yunus in 2006. A fact that has undoubtedly widened the perception that the road to Social Business is viable and promising.

The interplay of the described forces helps explain the emergence of a few examples of Social Multinationals which were observed in real world. However, their emergence as a stable and more than occasional form of entrepreneurship would require the development of several institutional and organisational conditions. Some of these were highlighted in the pathbreaking book by Yunus (2008b) where the concept of Social Business has been systematised. Without pretension of providing a full discussion of this crucial issue, we shall mention at least four such conditions which play a key role for the development of Social Multinationals.

\footnotetext{
${ }^{5}$ The share of unfavourable regulatory changes has further increased to over $24 \%$ in 2008 , in the presence of some reduction of the number of legal measures reported (110) and of countries involved (55).
} 
First, new financial institutions are needed to connect investors with Social Businesses. Yunus (2008b) envisages the creation of a social stock market where only the shares of Social Businesses will be traded. Investors will come to this stock-exchange in order to find a Social Business, which has a mission to his or her liking, just as someone who wants to make money goes to the existing stock-market. Businesses will need to be evaluated according to the social objectives they pursue, and to the effective attainment of such objectives.

Second, to enable a social stock-exchange to perform properly, some complementary institutions and actors are also necessary. We will need to create rating agencies, to have them agree on standard terminology, definitions, impact measurement tools, and reporting formats. To monitor markets for Social Business and inform investors on the available projects, specialised financial publications and electronic media will also have to be issued. An entire body of norms will have to be developed at all levels national and supra-national - to regulate the new markets of financial products as well as of social goods and services, and regulatory agencies will have to ensure fair competition here too.

Third, human capital will have to be trained to capture new Social Business opportunities. Some of the competencies needed to develop such activities are quite the same as those that are necessary for any innovative activity, and will be accumulated through the same patterns: higher education, technical and managerial training, learning processes. However, as the market for Social Business expands, there will be higher needs for specialised educational and learning profiles. Young managers will have to be trained in specialised business courses. Technical capabilities will more and more have to be adapted to specific social needs and to the environments in which such needs have to be tackled.

Fourth and last, but not least, aid policies of national and supra-national institutions should be re-designed consistent with the objective of expanding international Social Business. Part of these financial flows could be redirected to fund Social Business in key areas of intervention. Yunus (2008b) ventures to suggest that World Bank's International Finance Corporation Agency should be substituted with a newly designed one expressly dedicated to Social Business. 


\section{References}

Asongu, J.J. (2007). The History of Corporate Social Responsibility. Journal of Business and Public Policy History, 1(2). 1-18.

Blomstrom, M., \& Kokko, A. (1998). Multinational Corporations and Spillovers. Journal of Economic Surveys, 12(3). 247-277. doi:10.1111/14676419.00056

Castellani, D., \& Zanfei, A. (2006). Multinational Firms, Innovation and Productivity. Cheltenham, UK: Edward Elgar.

Collins, D., Morduch, J., Rutherford, S., \& Ruthven, O. (2009). Portfolios of the Poor: How the World's Poor Live on \$2 a Day. Princeton, NJ: Princeton University Press.

Daley-Harris, S. (2007). State of the Microcredit Summit Campaign Report 2007. Washington, DC: Microcredit Summit Campaign.

Retrieved from: http:/ / www.microcreditsummit.org

Dart, R. (2004) .The Legitimacy of Social Enterprise. Nonprofit Management $\mathcal{E}$ Leadership, 14 (4). 411-424. doi:10.1002/nml.43

Driffield, N., \& Love, J.H. (2007). Linking FDI Motivation and Host Economy Productivity Effects: Conceptual and Empirical Analysis. Journal of International Business Studies, 38(3). 460-473. doi:10.1057/palgrave.jibs.8400268

Egri, C.P., \& Ralston, D. (2008). Corporate Responsibility: a revRiew of International Management Research from 1998 to 2007. Journal of International Management 14(4). 319-339. doi:10.1016/j.intman.2007.09.003

Görg, H., \& Greenaway, D. (2004). Much Ado about Nothing? Do Domestic Firms Really Benefit from Foreign Direct Investment? The World Bank Research Observer, 19(2). 171-197. doi:10.1093/wbro/lkh019

Haskel, J.E., Pereira, S.C., \& Slaughter, M.J. (2007). Does Inward Foreign Direct Investment Boost the Productivity of Domestic Firms? Review of Economics and Statistics, 89(3). 482-496. doi:10.1162/rest.89.3.482

Hollander, H. (1990). A Social Exchange Approach to Voluntary Cooperation . American Economic Review, 80(5). 1157-1167.

Retrieved from: http://www.jstor.org/stable/2006767

Kaldor, M., Anheier, H., \& Glasius, M. (2003). Global Civil Society in an Era of Regressive Globalisation. In London School of Economics, Global Civil Society 2003. Oxford: Oxford University Press. 
Khandker, S. R. (2005). Microfinance and poverty: Evidence Using Panel Data from Bangladesh. World Bank Economic Review, 19(2). 263-286. doi:10.1093/wber/lhi008

McDonald, C., \& Marston, G. (2001, November). Fixing the Niche? Rhetoric of the Community Sector in the Neo-Liberal Welfare Regime. Paper presented at the Workshop Social Entrepreneurship: whose responsibility is it anyway? Centre for Full Employment and Equity and the Department of Social Work, The University of Newcastle.

Narula R., \& Zanfei, A. (2005). Globalisation of Innovation. In Fagerberg, J., Mowery, D., \& Nelson, R.R. (Eds.). Handbook of Innovation (pp. 318-345). Oxford: Oxford University Press.

Nelson E. (2007, November 16). Microcapital Story: Taking Stock of Global Microfinance Statistics on Global Assets and Customers [Web blog post]. Retrieved from: http:/ / www.microcapital.org/

Niño-Zarazúa, M. (2009). The Impact of Microcredit on Income poverty. An Endogeneity-Corrected Estimation in Urban Mexico. Working paper, University of Sheffield. Retrieved from: http://www.scribd.com/

Pitt, M.M., \& Khandker, S.R. (1998). The Impact of Group-Based Credit on Poor Households in Bangladesh: Does the Gender of Participants Matter? Journal of Political Economy, 106(5). 958-996. doi:10.1086/250037

Roodman, D., \& Morduch, J. (2009). The Impact of Microcredit on the Poor in Bangladesh: Revisiting the Evidence. (CGD Working Paper 174). Retrieved from: http://www.cgdev.org/

Socinfo (2009), Social Entrepreneurship and ICT: Business and Human Development in the Caribbean, www.socinfo.com

UNCDF (2005). Microfinance and the Millennium Development Goals. Geneva

UNCTAD (2008). World Investment Report. Transnational Corporations, and the Infrastructural Challenge. Geneva

Yunus, M. (2008a, December). Adam Smith Lecture. Glasgow University, December 1, 2008. Retrieved from: http:/ / www.socialbusinessearth.org/theadam-smith-lecture/

Yunus, M. (2008b). Creating a World Without poverty: Social Business and the Future of Capitalism. USA: Public Affairs, Perseus Books.

Yunus, M. (2008c, June). Each of You has the Power to Change the World. MIT's 142nd Commencement, Massachusetts Institute of Technology, Cambridge, MA, June 6, 2008. 
Zanfei, A. (2005). Globalisation at Bay? Multinational Growth and Technology Spillover. Critical perspectives on international business, 1(1). 5-17. 